Housing Studies

\title{
When homes earn more than jobs: the rentierization of the Australian housing market
}

\section{Josh Ryan-Collins \& Cameron Murray}

To cite this article: Josh Ryan-Collins \& Cameron Murray (2021): When homes earn more than jobs: the rentierization of the Australian housing market, Housing Studies, DOI: 10.1080/02673037.2021.2004091

To link to this article: https://doi.org/10.1080/02673037.2021.2004091

$$
\begin{aligned}
& \text { (c) } 2021 \text { The Author(s). Published by Informa } \\
& \text { UK Limited, trading as Taylor \& Francis } \\
& \text { Group. }
\end{aligned}
$$

\section{曲 Published online: 28 Nov 2021.}

Submit your article to this journal $\pi$

Q View related articles $₫$

View Crossmark data $\nearrow$ 


\title{
When homes earn more than jobs: the rentierization of the Australian housing market
}

\author{
Josh Ryan-Collins ${ }^{\mathrm{a}}$ (D) and Cameron Murray ${ }^{\mathrm{b}}$ \\ anstitute for Innovation and Public Purpose, University College London, London, United Kingdom of \\ Great Britain and Northern Ireland; ${ }^{b}$ Henry Halloran Trust, University of Sydney, Sydney, Australia
}

\begin{abstract}
This article develops the concept of housing market 'rentierization' to describe the shift in the treatment of housing away from its use as a consumption good to an asset from which economic rent can be extracted. Rentierization encompasses, but goes beyond, the 'financialisation of housing' that has been the focus of attention in the recent political economy of housing literature as it involves changes across land and housing market policy, fiscal-policy as well as financial policy spheres. We examine Australia as a canonical example of rentierization, conducting a historical case study that examines the returns to land and housing over the $20^{\text {th }}$ century and trace its roots to developments that preceded the financial liberalization of the 1980s, including the privatization of public housing in the 1960s and 70s.
\end{abstract}

\section{ARTICLE HISTORY}

Received 7 August 2020

Accepted 18 October 2021

\section{KEYWORDS}

Housing; land; economic rent; financialization; privatization; credit; taxation;

homeownership; Australian economy

JEL

R21; R30; R31; R38; 018; E44; G21; G28

\section{Introduction}

Housing affordability is a major economic and public policy challenge for advanced economies (The Economist, 2020). In recent decades attention has turned to the demand for housing as a financial asset as well as a consumption good in determining house prices. The term 'financialization of housing' has become established in the literature to describe this trend and the wider role of the financial sector in determining house market dynamics. Housing financialisation is usually dated from the liberalization and deregulation of mortgage finance in the 1980s and 1990s, continuing through to the globalization of housing finance via residential-mortgage backed securitization in the 2000s (see, inter alia, Aalbers, 2016; Gotham, 2009; Rolnik, 2013). It is a term that has been subject to critique for being vague and amorphous (Christophers, 2015; French et al., 2011) but remains the dominant frame for describing recent changes in high-income economy housing markets.

CONTACT Josh Ryan-Collins j.ryan-collins@ucl.ac.uk $@$ Institute for Innovation and Public Purpose, University College London, London, United Kingdom of Great Britain and Northern Ireland.

(c) 2021 The Author(s). Published by Informa UK Limited, trading as Taylor \& Francis Group.

This is an Open Access article distributed under the terms of the Creative Commons Attribution-NonCommercial-NoDerivatives License (http://creativecommons.org/licenses/by-nc-nd/4.0/), which permits non-commercial re-use, distribution, and reproduction in any medium, provided the original work is properly cited, and is not altered, transformed, or built upon in any way. 
In this article we develop the concept of housing market 'rentierization' as an alternative, demand-side conceptual framework for understanding the transformation of housing markets in advanced economies. Drawing on classical political economy, by rentierization we mean a broad shift in both policy, and in market and household behaviour, towards the treatment of housing as a source of economic rent extraction rather than a source of (affordable) shelter and security. We argue this concept is more analytically useful than financialisation, since finance is just one policy sphere that impacts on the shifting treatment of housing. Other key spheres are shifts in land and housing market policies and fiscal policy, in particular housing taxation. ${ }^{1}$ Without changes in these policies, housing rents cannot be realized by either the financial sector, households or other agents.

We use Australia as a historical case study to study rentierization. We show that housing returns in Australia have become a dominant income source (in some cases more substantial than wages); that home equity as well as home ownership rates (which peaked ahead of most countries in the 1960s) have declined, meaning land rents have become more concentrated; and that patterns of (speculative) investment rather than home ownership seem to be a key driver of price formation in housing markets. These factors, combined with the political power of home owners, make rentierization of Australia's housing market a canonical, and hence informative, case in a global trend.

The remainder of this article is set out as follows. In Section 2 we define what we mean by rentierization and situate our approach in the related literature. Section 3 is a historical case study of the Australian housing market, focussing on land and housing policy, financial policy and tax policy. Section 4 considers the reasons behind the resilience of Australia's rentierized housing model, suggests policy alternatives, and also challenges the recently emerging narrative from some economists that rising house prices are primarily driven by the long-term fall in real interest rates. Section 5 concludes.

\section{Conceptualizing housing-market rentierization}

\subsection{Related literature}

Economic rent is income extracted from ownership or control over an asset required for economic production in excess of the costs required to maintain that asset or activity in use. Land was recognized by the classical economists Ricardo, Mill and Smith as the most important resource from which rentier income could be extracted. Unlike the other factors of production, such as produced capital and labour, land is inherently scarce in supply yet vital for production. As a result, landowners are natural monopolists, able to absorb an increasing portion of the economic surplus as the economy grew, reducing the funds available for capital investment and wages necessary for capitalist growth (George, 1884; Ryan-Collins et al., 2017). Rents can also be generated from assets that are not naturally scarce via the creation of monopolistic controls (e.g. patents) or other competition-reducing interventions.

In modern times the most valuable land use is residential housing. Housing is a composite good consisting of property rights to a location (the land) and the 
structures built upon that land (the capital). With the spread of home ownership to the middle classes following World War II, land and land rents became less concentrated than in the times in which the classical economists were writing, when a limited number of land-owners controlled the majority of land. Yet land rents remain and have been growing rapidly in the last four decades.

The huge increases in home prices relative to incomes in advanced economies in the post-ward period were mainly in the form of rising land values, accounting for around $80 \%$ of growth since the 1950 s on average, with construction/replacement costs increasing only at the rate of inflation (Knoll et al., 2017). Wealth accumulation since the 1970s in many capitalist economies has largely been driven by increases in property prices via capital gains, rather than increases in profits from the production of goods and services (Rognlie, 2014; Stiglitz, 2015). Across advanced economies, the return on housing (capital gains and rental yield) has averaged $7 \%$ (Jordà et al., 2019). This is over twice as high as that on benchmark financial assets (government bonds/Treasury bills) and similar to equities, but with markedly less volatility, in particular since World War II (ibid). The term 'safe as houses' has some merit from an investment perspective.

Noting these developments, urban economic geographers and political economists revisited the classical concept of land rents in the 1980s, arguing they were becoming central to modern capitalist patterns of accumulation and had a coordinative as well as exploitative function (Ball, 1985; Haila, 1988; Harvey, 1978, 1982). It proved challenging, however, to develop an overarching theory of land rent, partly because it was recognized that social, cultural and political dynamics mediate urban rent creation and extraction. However, in determining modern land-rent extraction patterns, less attention was given in these debates to financial and macroeconomic policies at the national level (Ryan-Collins, 2019).

One of the first scholars to pose systemic questions about housing and political economy in Australia was Jim Kemeny (1978, 1983). Kemeny challenged the prevailing ideology of home ownership, claiming it was a key means via which certain interests, in particular 'finance capital', are able to generate profits from the housing sector, driving up the cost of housing overall and inequality of access to housing as a by-product. Kemeny was critiqued for placing too much emphasis on home ownership itself (a form of consumption of housing) rather than the system of housing provision, and its underlying social and economic structures, as the driver of housing inequality (Ball, 1983; Hayward, 1986). The Australian system was notable for its failure to provide for a decent quality, sustained public housing option, making home ownership a rational and culturally dominant tenure choice, including for the working class (Hayward, 1986).

Since the 1990s the financial sector has become a focus of Austalian housing scholars. Many studies have identified the role of financial liberalization and increased mortgage credit flows as a driver of prices (Berry, 1999; Burke \& Hulse, 2010; Williams, 2009; Yates, 1994; Yates \& Yanotti, 2016). However, very few studies have related the growth of finance back to land rents. One exception is Putland (2018), who estimates that land rents (rental values plus smoothed realized capital gains) have increased from $2 \%$ of GDP in the 1950 s to more than $20 \%$ by 2017 . 
Recently, post-financial crisis interventions have focussed on the 'financialisation of housing' (as opposed to land explicitly) as a key channel via which finance capital extracts value from housing markets (Aalbers, 2016; Gotham, 2009; Rolnik, 2013). Housing market financialisation has also been theorized as supporting the emergence of 'asset-based welfare', enabling the state to withdraw from universal provision of social security with property wealth taking its place as a new, but socioeconomically uneven, safety net (Doling \& Ronald, 2010; Kemeny, 2005; Ronald et al., 2017; Watson, 2010). Some scholars have proposed that the rapid rise in house prices, coupled with declining levels of homeownership, is creating a new form of social stratification whereby life chances may be more affected by whether you own a home or not than your occupation (Adkins et al., 2019, 2020; Arundel \& Ronald, 2021; Forrest \& Hirayama, 2018).

Financialisation has been critiqued for being excessively vague and amorphous (French et al., 2011) failing to distinguish between categorization and explanation (Christophers, 2015) and neglecting important institutional and legal frameworks (Poovey, 2015). It has been used by different researchers to describe different processes even within the context of housing, ranging from changes in household attitudes towards mortgage debt to shifting macro-level trends such as the privatization of the rental sector and shifts in global housing investment. As with the urban rent theory literature noted above, parts of the housing financialisation literature have emphasized is variegated nature and the diversity of forms of 'residential capitalism' (Fernandez \& Aalbers, 2016; Schwartz \& Seabrooke, 2008). Nevertheless, it remains a loosely defined concept which perhaps limits its analytical precision.

Economists have modelled house prices as an outcome of supply and demand factors and a price adjustment process which brings these in to equilibrium. The demand for housing is typically modelled as a function of disposable income, the user cost of housing and demographic factors (Andrews et al., 2011; Poterba, 1984; Sommer et al., 2013). One recent example is Meen \& Whitehead (2020) who model house prices in the UK. They examine two demand side variables: a) consumption demand, represented by household income, and b) asset pricing factors, which are captured in a User Cost of Capital (UCC) equation including interest rates, taxation, depreciation and price expectations. Based on this approach, they suggest that the long-run growth of housing prices are primarily due to consumption demand rather than housing's role as an asset, since they find that the long-run UCC has not changed over time, although has been subject to short-term volatility.

However, disentangling 'consumption demand' from speculative or rentier-demand for housing is not easy given that speculative motives are not observable. Measuring expected house price appreciation is particularly challenging in UCC estimates since surveys of house price expectations are relatively sparse and intermittent (Muellbauer, 2012). Many studies find little evidence of rational, 'life-cycle savings' type-behaviour assumed standard economic models in relation to house price expectations (Capozza \& Seguin, 1996; Case \& Shiller, 1990; Clayton, 1997). Meen \& Whitehead (2020) estimate expectations based the annualized actual rate of house price inflation over the past six months (based on earlier work by Meen (2009)). But a number of studies estimate the lagged 4 or 5 year rate of appreciation as a stronger candidate for expectations as part of the user cost (Cameron et al., 2006; Duca et al., 2011; 
Himmelberg et al., 2005). This has important implications for the overshooting of housing prices, implying a series of positive shocks will cause further appreciation over a considerable period even if fundamentals (interest rates, taxation) do not change or revert to a long-run mean (Muellbauer, 2012, p. 81).

In this sense, the extrapolative expectation of rentier returns (capital gains on land in this case) can be seen to create its own demand, reducing the efficacy of equilibrium type models. This pattern has also been observed in Australia where Muellbauer \& Williams (2011) propose a 'frenzy' phenomenon whereby when housing price rises exceed thresholds given by transaction costs and costs of finance, the potential speculative gains become so attractive that the number of bidders in the housing market rises sharply, resulting in an acceleration of housing prices.

More generally, UCC type approaches are unable to capture how a range of institutional and policy shifts, distributional and cultural dynamics may influence the rentier demand for housing. These include, for example, the availability and quality of non-market housing available to households and particular tax breaks or debt subsidies for investors in property (particular relevant to Australia as we shall see in Section 3). A further limitation standard economic modelling of house prices is that the variable of interest is house prices rather than (residential) land; however evidence suggests land and structures have very different price dynamics meaning aggregating them together may disguise information (Davis \& Heathcote, 2007). Although we should note that the objective of our paper is not to propose an alternative methodology of forecasting house prices, our broader rentierization approach encompasses the supply-demand conceptualization of housing prices, but allows for the consideration of policy settings that feed in to each supply or demand factor.

\subsection{Key dynamics of housing-market rentierization}

Our concept of rentierization builds on insights from this aforementioned literature. However, we focus on a wider policy agenda beyond finance - including land and housing policy and fiscal policy in particular - as we think policy shifts in these fields have been key to enabling land rent extraction and that this concept provides a more analytically coherent concept for understanding common shifts in the political economy of housing markets. Rentierization has three mutually reinforcing features.

Firstly, the dominance of private landed home ownership as the preferred form of tenure. The term 'landed' is important here for it is the land (or location) that is the primary driver of economic rents related to property (namely capital gains and ground rents). Home ownership, per se, does not have to lead to privatized rent extraction since the ownership of land can be separated from the ownership of the home. Land can be publicly or cooperatively owned and its value also captured by the state via taxation. This is the case in some East Asian economies, notably Singapore, Hong Kong and to some extent South Korea (Haila 2015).

Examples of policies supporting landed home ownership include withdrawal from public housing development and the privatization of existing public housing and 
land on a large scale (Aalbers \& Holm, 2008; Christophers, 2018). Or it can be the abandonment of policies enabling the purchase and assemblage of land at existing (e.g. agricultural) use values via compulsory purchase powers or via infrastructure levies that enable the development of new settlements with minimum rent extraction by existing land owners.

Secondly, housing market rentierization requires a liberalized financial system where a large proportion (if not a majority) of bank lending supports the purchase of existing property. Households use newly created credit to bid up prices via leveraging their incomes and more money flows into a limited supply of desirably located housing. As is common in asset markets, this home price growth itself attracts more demand for home buying as an investment, leading to higher leverage and larger mortgages as house prices accelerate away from incomes in a positive feedback cycle (Ryan-Collins, 2018, 2019).

Since banks collateralize their mortgages against the property being purchased, collateral values rise in parallel with debt, providing confidence to continue lending. In addition, liberalization involves the creation of a large and liquid secondary market in mortgage-backed securities, drawing in the institutional investment sector. As land values rise, so economic rents rise, but the financial sector (both banks and investors who purchase mortgage-backed securities from banks) extract an increasingly large proportion of this rent from home owners as interest payments on ever larger mortgages (Hudson, 2010).

However, liberalized finance also typically allows home owners to monetize a proportion of land rents via home equity withdrawal. This means housing can help fund consumption in the short to medium term, as well as enabling longer term wealth gains and wealth transfer. At the macroeconomic level, home equity withdrawal mediates the dampening effect on consumption of rising house-price-to-income ratios and rising mortgage debt-service ratios. An expected outcome will be declining household home equity over time, suggesting ultimately it may not be a sustainable form of consumption demand.

Thirdly, rentierization is supported by a tax regime that favours landed property both as a form of tenure and as a financial asset. In most advanced economies, capital gains on primary residences are tax free, unlike nearly all other financial assets, and there is no imputed rent tax. Recurrent property taxes or transaction-based property taxes are more common, but generally low or based on infrequent revaluation.

These above three phenomena are mutually self-reinforcing. Both home owners and housing investors have a strong interest in their property value increasing to privately capture these rents. Financial actors have a strong interest in home ownership becoming the dominant form of tenure and in reducing property taxes in order to increase the demand for mortgage credit and hence profits (rents). Meanwhile, governments become drawn into the rentierization process once home ownership becomes established as the most desirable form of tenure and a vote winner. An alignment of political interests with the financial interests of rentiers also creates avenues for regulatory and policy capture via revolving doors between government, developers and the banking system (Gurran \& Phibbs, 2015; Jacobs, 2015; Murray \& Frijters, 2017). 
Table 1. Symptoms of rentierization.

\begin{tabular}{lc}
\hline Symptom & \multicolumn{1}{c}{ Description/indicator } \\
$\begin{array}{l}\text { Returns to owning housing dominate economic } \\
\text { incomes }\end{array}$ & $\begin{array}{l}\text { Wages form a smaller part of total household } \\
\text { economic gains relative to the return from home } \\
\text { ownership }\end{array}$ \\
$\begin{array}{l}\text { Increased dominance of bank lending and investor } \\
\text { behaviour in setting market prices }\end{array}$ & $\begin{array}{l}\text { Investor buying, supported by bank lending, will } \\
\text { become a larger share of home purchases, and } \\
\text { their entry and exit from the market will be the }\end{array}$ \\
$\begin{array}{l}\text { Decline of home ownership and reduction in } \\
\text { home-equity of owners }\end{array}$ & $\begin{array}{l}\text { mecause of the growing financial hurdles to home } \\
\text { ownership, more households will rent for longer } \\
\text { portions of their life and recent homebuyers will } \\
\text { have larger mortgages, taking longer to repay }\end{array}$ \\
\hline
\end{tabular}

A country experiencing rentierization of its housing market would exhibit the symptoms described in Table 1. Excess economic rents accruing to home owners will come to dominate the available incomes in the economy, having a large influence on investment decisions. Home owners will, on average, own less of their home, as more recent buyers increase leverage to outbid investors at higher prices. Investor buyers will grow as a share of the housing market, as they have strong incentives to speculate on the excess rents to housing. Finally, home ownership rates will decline as fewer households are able to meet the financial hurdles of ownership.

As we show in the next section, Australia fits this categorization well. Indeed, it can be viewed as an ideal type with regard to housing market rentierization with few limits on the pursuit of unearned income from real estate. This contrasts other advanced economies which have generally had more substantive provision of non-market housing, although more so in Europe than the U.S. However, the direction of travel for many advanced and emerging market economies would appear to be towards rentierization as the role of finance grows in the housing sector and forms of privatization - including of the social and private rented sector - continue to emerge (Aalbers 2016; Rolnik 2019; Ryan-Collins 2018). This makes Australia an interesting case for considering future trends.

\section{The rentierization of housing and land in Australia: a historical case study}

\subsection{A Long-term view of the returns to land}

As noted in Section 2, a simple way of comprehending the rent that accrues to property is to examine the returns to land, normally including both ground rent and increases in value over time, or capital gains. What are the long-term dynamics of the returns to land and housing in Australia? Despite multiple major boom and bust cycles, including the infamous 1880 s land boom, ${ }^{2}$ land values and home prices were relatively low compared to the total value of economic activity in the century prior to the 1960s. In contrast, since 1980, real Australian home prices have increased $215 \%$ and have shown few signs of reversion to long-term trends, despite brief corrections in 2009-10 and 2017-2019. The rise in Australian house prices has been driven by rising land values (Figure 1), as construction costs have grown at a rate closer to general price inflation. 


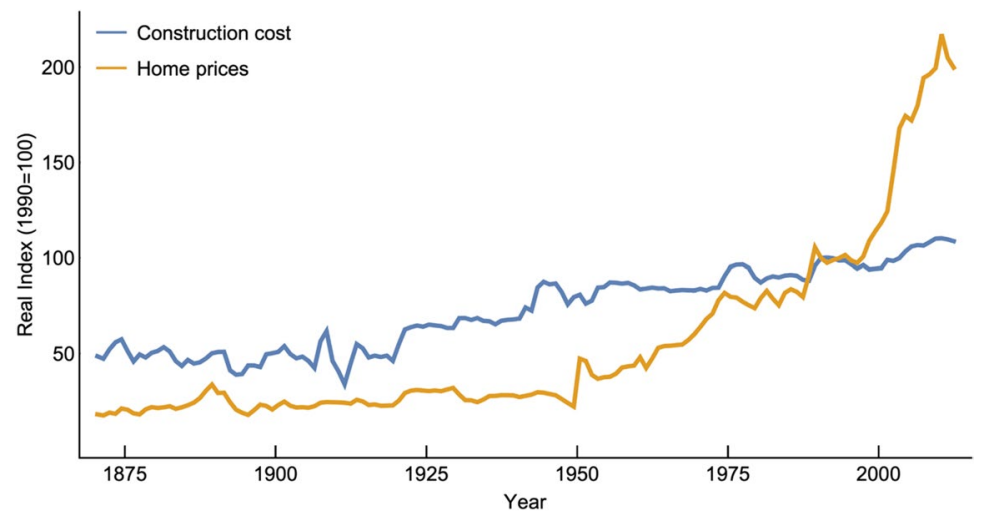

Figure 1. Long-term Australian real price index for housing and construction prices. Source: Knoll et al. (2017).

When compared to the total value added in the economy, Australia's land values, which are dominated by residential land in the capital cities, surpassed their previous record peak in the early 1980s and have continued to grow, with few temporary interruptions to the trend. Figure 2 shows how large the economic returns to land and housing have become relative to Gross Domestic Product (GDP). The returns to land for housing in the form of value gains show a structural increase since the end of the 1970s, with the 1960-80 period having a mean annual value gain of 9.3\% of GDP and the 2000-20 period having a much higher $16.8 \%$ of GDP annual value gain, although with some volatility during each period. Adding in rents from ownership of housing shows that the economic gains to housing owners since 2000 has been $24 \%$ of GDP on average. These developments certainly support the argument made in the recent literature (described above) that property-ownership is becoming a key driver of life chances and inequality and arguably more important

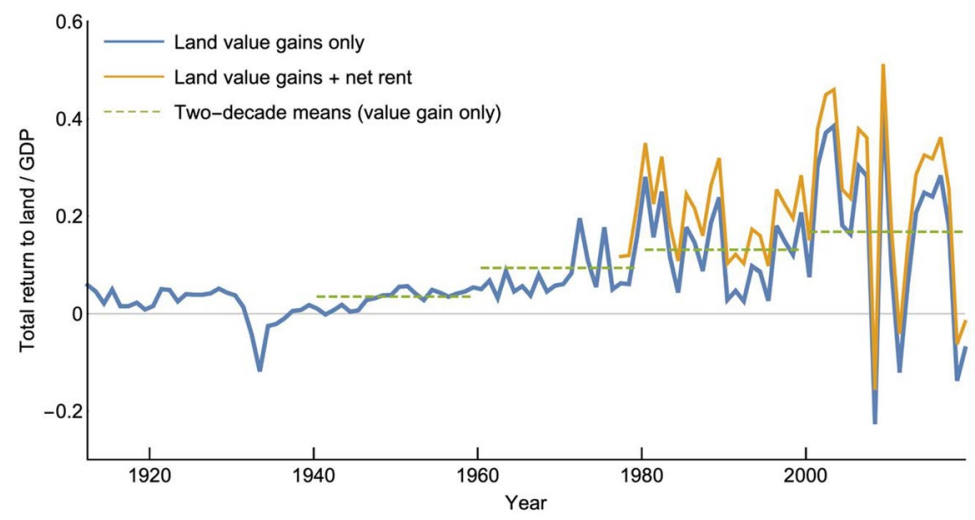

Figure 2. National property returns compared to GDP. Note: Land value series is compiled from Scott (1969), Scott (1986) and ABS (2019a). The GDP series is from Butlin (1985) and ABS (2019b). Land value gain to GDP is the annual change in total land value divided by the GDP. From 1979 residential rents and imputed rents of owner-occupiers from ABS (2019b) are included in the numerator of the calculation. 


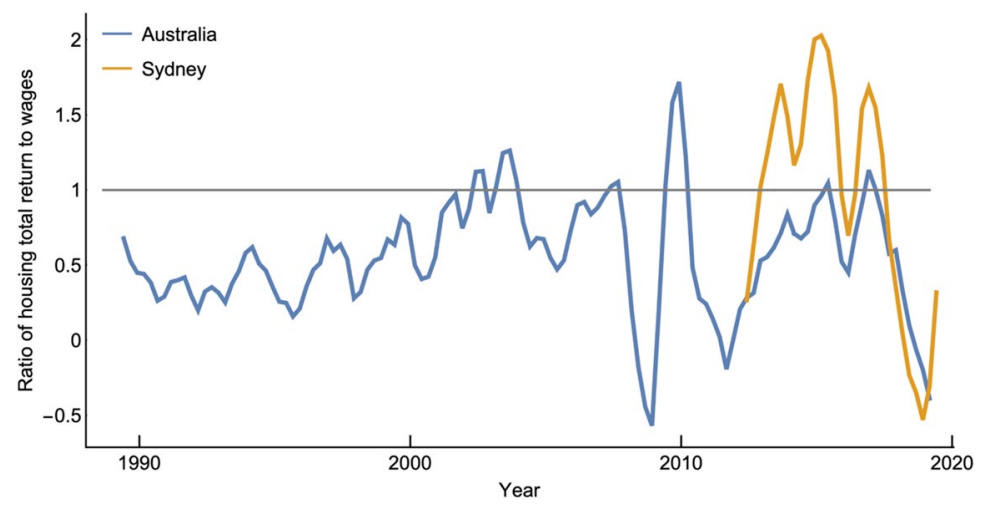

Figure 3. Total return from housing and wages in Australia and Sydney.

Note: For Australia, calculated as (Change in housing stock value - Housing capital investment + Net rents) / Total employee compensation); and for Sydney as (Change in median Sydney dwelling value + Median house rent) / Median NSW full-time wage) (ABS, 2019b, 2019g, 2019h; SQM, 2019).

than occupation in determining life chances and class identification (Adkins et al., 2020; Arundel, 2017; Forrest \& Hirayama, 2018)

To further demonstrate the outsized scale of returns to landed property, we can compare the annual return to a typical home over a year with the return to labour in the form of wage income, both nationally and for Sydney (where only recent data is available) in Figure $3 .^{3}$ When this metric is greater than one it implies that the average home had a larger annual economic return, made up of rent and capital gains, than the average worker. Prior to June 2019, in 16 of the previous 29 quarters (55\% of the time) we find that the median Sydney home earnt more than the median full-time worker.

These historical snapshots suggest that the returns to housing have begun to dominate incomes in the Australian economy. These figures are averaged across an enormous continent with considerable diversity across regions. However, this long-term view does suggest a structural shift in the economy since the 1980s. The rise in the returns to land is not only a radical deviation from the post-war norms, but a deviation from a century-long norm that cannot be easily attributed to cyclical market dynamics. How then, did this state of affairs come about?

\subsection{The drive towards landed home ownership}

Like many other nations, rapid post-war growth in home ownership - involving the democratization of economic rents - is a feature of the Australian story. However, home ownership rates peaked in the mid-1960s, much earlier than other comparable economies. Since then it has flatlined until the early 2000s, when it began an unprecedented decline, from $70 \%$ to $65 \%$, in the following decade. Similar declines have occurred in other Anglo-Saxon housing markets, such as the UK and the US (Ryan-Collins 2018).

The rise in home ownership was the product of policy.The Commonwealth and state governments directly contributed 221,700 , or $24 \%$ of the total increase in the housing stock, through programmes financed under the Commonwealth State 
Housing Agreements (CHSAs) or under the War and Defence Service Homes Schemes (Eslake, 2013, p. 2). By 1956 War Service Home Loans constituted 20\% of all housing finance, with government housing authorities providing another $8.8 \%$ on top of state and federal funds made available through the savings banks (Kemeny 1978).

Public funds for housing were overwhelmingly allocated to the construction of new housing. In 1956 almost three-quarters of War Service loans were for new housing, compared to one-third for major trading bank loans (Hill, 1959). Public housing finance was complemented by rising wages and economic growth to propel a large expansion in the private building of homes, with new dwelling construction running at about 80,000 per year during the 1950s. Between 1947 and 1961 the housing stock increased by $50 \%$, compared with a $41 \%$ increase in Australia's population over this period. Owner-occupation levels reached $63 \%$ by the mid-1950s, well ahead of most other industrial economies (Berry, 1999).

While the original CSHA envisaged the development of a strong public rental sector to serve as an alternative to privately financed housing, public finance constraints prohibited the expansion of public rental housing. Around $15 \%$ of new dwellings were public housing in the decade following the war, but by the early 1950s many states wished to sell housing built with CSHA funds due to financial losses. Increasing rents to meet the shortfalls was not possible due to ongoing rent controls (Beer, 1993, p. 153). Many private landlords sold their dwellings in inner city areas to owner-occupiers.

The Liberal-Country Party coalition government that came to power in 1956 oriented public housing firmly back towards home ownership with the passing of the second CHSA. This diverted a significant proportion of CSHA funds into the building societies and allowed state housing authorities to sell public housing dwellings to sitting tenants on much more favourable financial terms than those available from private banks (Pawson et al., 2020). What followed was a vast privatization of public housing (Figure 4), a full two decades before the better known 'right to buy' privatization of public housing initiated by the Thatcher government in the UK in the 1980s. It was this privatization that enabled home ownership rates in Australia to reach a high of $71 \%$ in 1970 .

By 1971, 40\% of all housing built under the CSHA was in private hands, either built for immediate sale or sold from the public housing stock (Troy, 2011). The effect of this policy - which was pursued with some vigour until the early 1980s - was to privatize land rents on a massive scale. Yet the policy was popular because it supported rising home ownership among the middle and working classes. It helped establish home ownership as a key cultural and political requirement for Australian households, and in doing so these measures compounded existing and deeply embedded cultural preferences. While the Hawke government of the 1980s did invest in public housing, this was something of a blip on a generally downward trajectory. The 1996 CSHA further reduced funding for new homes and instead shifted towards the subsidization of rents. Since 2000 , only $2 \%$ of new homes have been publicly provided.

Today, 95\% of all housing in Australia is privately owned, a relatively high figure amongst advanced economies, and only $2 \%$ of new housing has been 


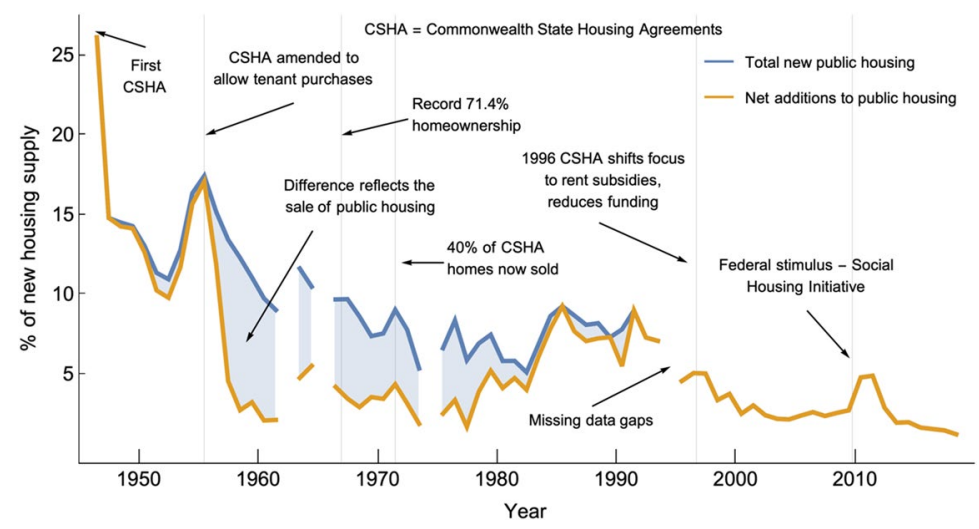

Figure 4. Share of new housing supply from public housing initiatives in Australia. Sources: Blue shaded area shows privatization of formerly public housing. Data from 1945 to 2001 is from Troy (2011). From 2002 to 2018 data is from ABS (2018).

publicly provided since 2013 (ABS, 2018). This near complete reliance the private sector to provide new housing also creates a rent allocation issue within a rules-based planning system. Changes to planning rules to allow higher value uses at certain locations, which are often necessary to direct where new private housing occurs, provide windfall land value gains - i.e. land rents - to private landowners rather than being captured by the public (Murray \& Frijters, 2016). Unlike some European and many East Asian countries, where public sector involvement in land supply for housing allows economic rents to be captured for the public (Phang, 1996; Shahab et al., 2021), Australian local and state governments lack the ability to capture planning gain and lack powers to require land to be brought into production when needed.

Another distinctive feature of the Australian system of housing provision is the separation of the building industry from the land development sector; in most countries these are usually combined into one as 'housing developers'. Land developers acquire land, obtain zoning rights, and then clear and subdivide the land, as well as putting in place the necessary infrastructure. They generate profits by selling parcels of subdivided land onto households, who buy it up and instruct builders to build their home according to a preferred specification.

This 'build-to-order' model results in land taking up a relatively large proportion of the value of housing relative to countries where multi-unit housing developments with high densities enable a reduction in land costs and create infrastructure savings (Burke \& Hulse, 2010). The beneficiaries are primarily the land developers and existing homeowners who monopolize increases in land value at the expense of builders and non-homeowners. As noted by Burke \& Hulse (2010) this may reflect to some extent an individualistic cultural preference for a single detached dwelling that enables homeowners to create a 'wraparound' lifestyle in a way which is not present in Europe and the UK.

Such a model is poorly designed from an affordable housing perspective, since if land values rise faster than incomes there will be less demand for new units and less building, pushing up prices and rents further. In addition, there is evidence of 
systemic land banking by developers, where land able to be profitably developed for housing is withheld from the market in anticipation of future gains, including capital gains. A recent study of the Queensland region found that over 200,000 housing lots, or 13 years of new supply, are held by the eight largest housing development companies, eight years' worth of which are held in housing subdivisions that are approved and already for sale (Murray, 2020a). In this sense the concept of 'landed property', and the rentier gains that go with it, are built into the DNA of the Australian system of housing provision.

In sum, the seeds of the rentierization were sown early in Australia relative to other advanced economies, well before the onset of market-oriented reforms to financial, fiscal and monetary policy of the 1980s. The strong cultural affiliation to landed home ownership, the use of public finance to subsidize private sector home loans and the privately owned building stock make Australia something of a unique case, although the US has some similarities.

\subsection{The liberalization and deregulation of housing finance}

A liberalized financial sector centred on lending to, and generating returns from, real estate is the second key characteristic of housing market rentierization. In Australia, the evidence for such a state of affairs is compelling. Figure 5 shows the total bank credit to GDP ratio for housing lending and business lending (defined as loans outstanding) since 1975. The former now dominates Australian bank balance sheets, with outstanding mortgage loans having risen from less than $15 \%$ of GDP in 1990 to over $80 \%$ today. Over the same period, outstanding loans to firms for investment and working capital - the textbook role of the commercial bank - has increased only slightly from about $38 \%$ to just over $40 \%$ of GDP. Similar patterns have occurred in other advanced economies but not to such extremes. A study of 17 advanced economies (including Australia) found that, on average, mortgage debt doubled between 1990 and 2020, increasing from about 35\% to 70\% (Bezemer et al., 2018, p. 6).

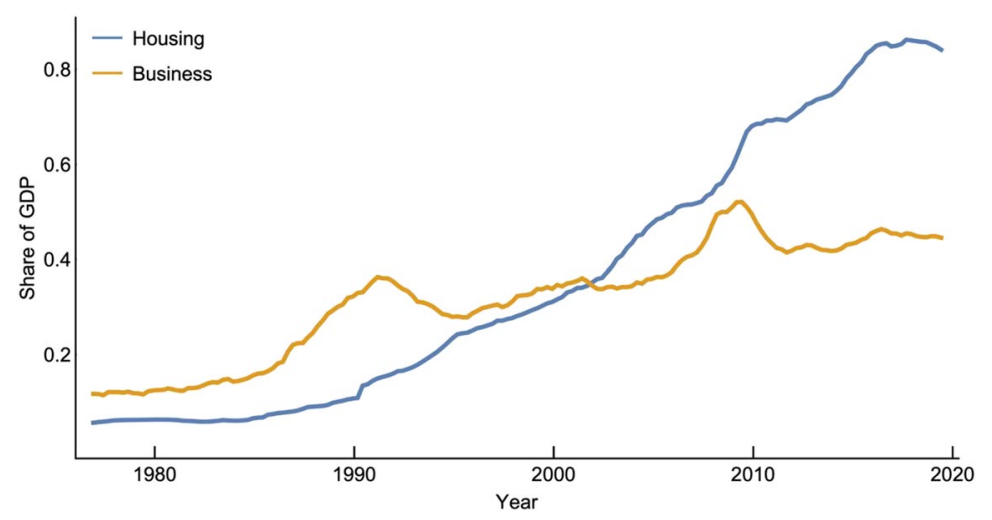

Figure 5. Bank credit (stock of outstanding loans) as a share of GDP. Source: Bank credit from RBA (2019) and GDP from ABS (2019b). 


\subsubsection{Financial liberalization and deregulation}

How did Australia's banking system transform into one so focussed on real estate lending? Australia's financial sector was strongly regulated in the post-war period, in common with most other industrial economies, with a range of qualitative, quantitative and price controls on bank lending and funding, alongside a fixed exchange rate and restrictions on foreign bank entry. Interest rates were not viewed as an effective tool for monetary policy, and were held below market rates to support active fiscal policy and social objectives, including affordable home ownership (Grenville, 1991).

The housing finance circuit was protected from the wider financial sector by regulations that required savings banks and building societies to limit the maximum interest rate they could charge on home loans and pay on deposits. Selective credit policies were used to direct lending towards priority sectors, including new housing and rural industries, well into the 1960s (Jones, 2003). Portfolio restrictions were also applied to the assets of savings banks, requiring them to hold a minimum $40 \%$ of liquid assets and government securities, which also helped finance the government (Yates, 1983). All of this meant that mortgage credit, although cheap, was effectively rationed for those on lower incomes. This was recognized as having the benefit of restraining house price inflation (Hill, 1959).

The entry of non-bank financial corporations into the financial system in the 1970s was viewed as reducing the effectiveness of these financial controls and stimulated the process of deregulation. The Australian Financial System Inquiry (AFSI) of 1981 resulted in the abolition of credit controls and portfolio restrictions (in 1982), the floating of the dollar, the abolition of the distinction between savings and trading banks, and the relaxation of entry restrictions. Deregulation led to greater competition in the financial sector in the late $1980 \mathrm{~s}$, most notably after the relaxation of the ceiling on mortgage interest rates for new loans in 1986 (Wood, 1990). The Commonwealth government also introduced capital adequacy guidelines, in line with the international Basel guidelines, which favoured housing mortgages which received a risk weighting of $50 \%$, compared to $100 \%$ for business loans.

During the 1980s the banking sector's share of the mortgage sector grew from $60 \%$ to $80 \%$ as there was a major consolidation of the Australian banking system (Kent \& Debelle, 1999). Building societies were unable to compete with the larger banks following deregulation and, in a process also seen in the UK, they merged, demutualised and were taken over by larger banks and financial groups. Credit unions also declined.

There was also a major privatization of the state-owned savings banks, which were the key conduits of government mortgage financing from the 1950s to 1970s as described in Section 3.2. By 1990, a third of the domestic assets of the banking system were controlled by five majority-owned government banks, including the largest and fifth largest bank. By 1999 all five had been either privatized or purchased by other banks (Gizycki \& Lowe, 2000, p. 192). While some states have continued to provide affordable housing finance to lower income households through direct lending programmes, these have operated on a relatively small scale (AIHW, 2018).

A further mortgage credit boom set in from the late 1990s up to the financial crisis of 2008. Mortgage loans outstanding more than doubled from 30\% to nearly 


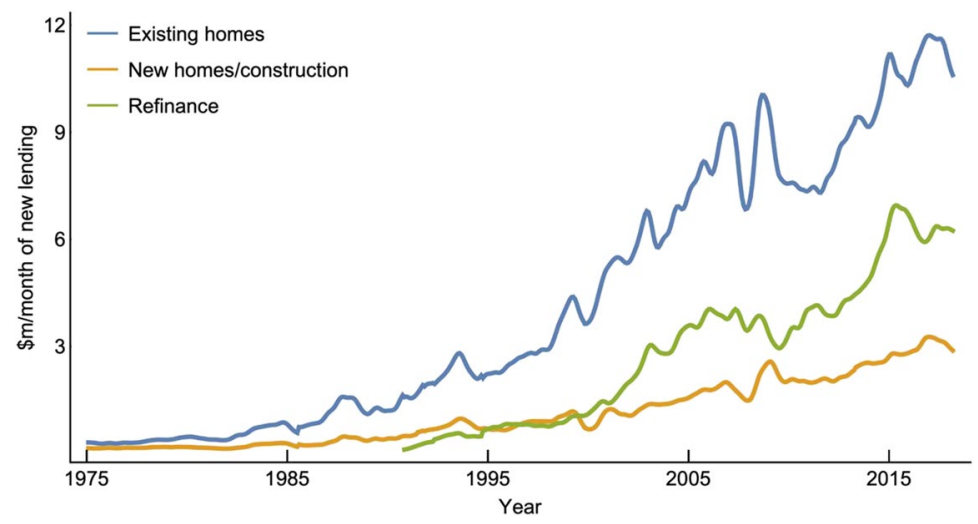

Figure 6. Value of lending to owner-occupied housing by type. Source: ABS (2019e).

$70 \%$ of GDP, in the process overtaking business lending (Figure 5). Unlike in other countries, this was primarily driven be an increase in rental investors who went from $15 \%$ of the market in 1996 to $29 \%$ by 2007.

Whereas the traditional focus of public housing finance (prior to 1996) was on the construction of new homes, for private banks, loans against housing development were more risky than lending for the purchase of established dwellings (Kemeny, 1978). The result was an increase of credit flowing to existing land and housing (Figure 6) with an inevitable inflationary impact on home prices (ABS, 2019e). This set in motion the housing-finance cycle (Ryan-Collins, 2018) that is key to the rentierization process, as described in Section 2.2, as higher prices generated greater demand for mortgage lending. Banks generated higher rentier profits from rising interest payments and fees from selling on Residential Mortgage Backed Securities (RMBS).

These dynamics occurred not just for investor lending, but owner-occupier lending as well. Lending to owner-occupiers to construct new dwellings fell from over $30 \%$ of owner-occupier lending in the 1970 s to less than $20 \%$ in the 2000 s (ABS, 2019e).

It is a common view that greater access to home finance is favourable, because it allows more people to enter the market and facilitates more home building. However, for Australia the data suggests that these claims are problematic. The increase in mortgage credit relative to GDP since the 1980s has not led to any increase in the rate of home ownership, which has flatlined since the 1960s and has been falling since 2006. The rate of home building has also fallen. Both investor and owner-occupier homebuyers only spend around a quarter of new mortgage debt on building new housing a level that has not significantly risen, despite major additional first-home buyer subsidies, as discussed further in Section 3.4. This supports a recent empirical study by Kohl (2018) showing that mortgage debt is negatively rather than positively correlated with home ownership across a panel of advanced economies, supporting the thesis that mortgage credit is capitalized into house prices.

The rentier-oriented dynamics of the Australian mortgage credit boom are also distinguished by the huge growth in credit for investor housing. Whereas the late 1990s and early 2000s mortgage credit booms supported home ownership and construction in many countries, in Australia this was predominantly an investor boom. The investor share of new mortgage lending grew from $10 \%$ in the early 1990 s to 


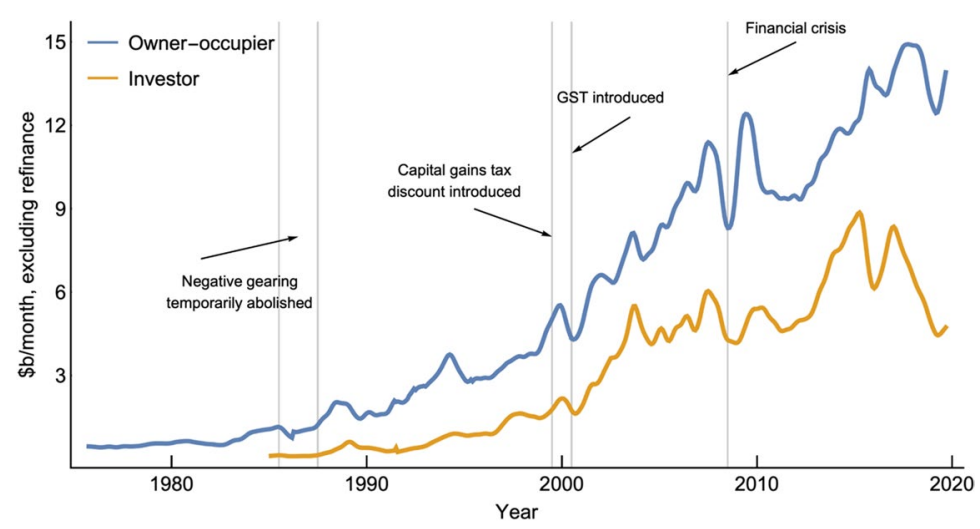

Figure 7. New monthly lending for home purchases, investors and owner-occupiers. Source: ABS (2019f).

$40 \%$ a decade later (Figure 7), while first-home finance approvals fell from almost $22 \%$ to around $17 \%$ of the total (Figure 9). This occurred despite repeated efforts by the Commonwealth government and more recently state governments to kickstart the First Home Buyer (FHB) mortgage market by offering grants, subsidies and tax discounts of various types.

Figure 7 shows the breakdown of monthly new investor and homeowner mortgage lending. From 1985 to 1995, investor lending averaged 14\% of new bank housing lending. From 2000 onwards it averaged 38\%, a substantial rise in the importance of investors in determining housing market outcomes. The recent decline since 2017 can be partly attributed to cyclical factors, but may also be the result of credit tightening following the Royal Commission into Misconduct in the Banking, Superannuation and Financial Services Industry. Banks responded to this inquiry by increasing interest rates on interest-only loans and tightening serviceability criteria, having a disproportionate effect on the ability of investors to finance housing purchses.

Significant financial innovations in the mid-1990s also saw the emergence of non-bank mortgage originators and mortgage brokers whose rapid growth was supported by the expansion of the residential mortgage backed securities (RMBS) market, which provided a relatively cheap funding source. As they were not regulated as strictly as deposit-taking institutions, these lenders took advantage of the cheap funding to introduce riskier, interest-only or low-documentation loans and revolving credit lines (Yates \& Yanotti, 2016, p. 43). By the time of the financial crisis, RMBS had grown in size from roughly $3 \%$ of bank mortgage funding in the mid-1990s to $25 \%$ (ABS, 2019c), though this proportion has been stable since. Low real interest rates enabled households to leverage up, leading to a trebling in debt-to-income ratios, a feature we explore further in the next section.

\subsubsection{Financial liberalization and home equity}

Home equity withdrawal enables households to monetize land rents, as discussed in Section 2.2. The trend in aggregate home equity (the share of total home values in excess of mortgage debt) has been steadily declining in Australia since the 1980s, from above $90 \%$ to $74 \%$ in 2019 (see Figure 8 ). This is a puzzle, since the major price booms 


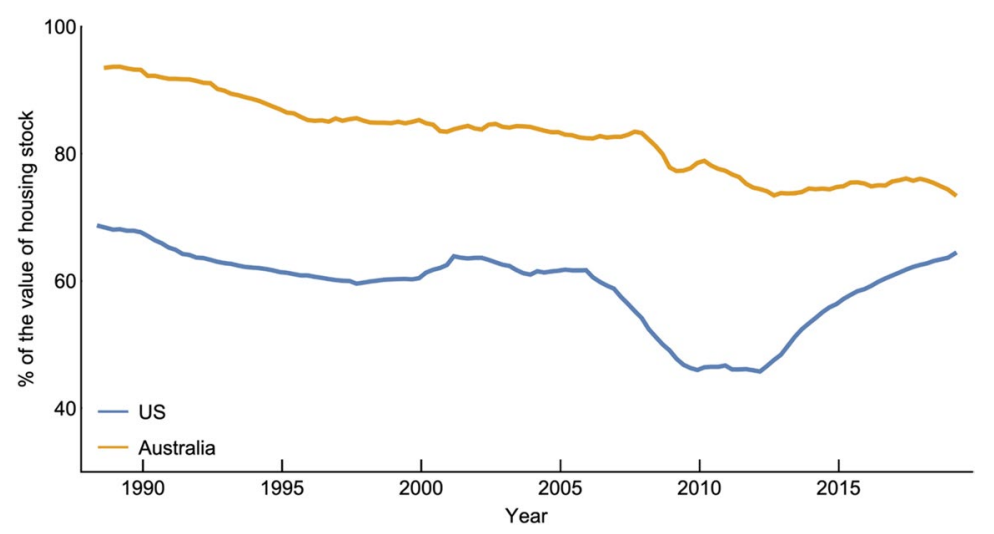

Figure 8. Home equity in Australia and the United States. Sources: For the US the data is home equity level for owner occupiers from FRED (2020a) divided by value of owner-occupied dwellings from FRED (2020b). For Australia, aggregate home equity is the total value of residential property from ABS (2019g) minus the total value of residential mortgages from RBA (2019), divided by the total value of residential property.

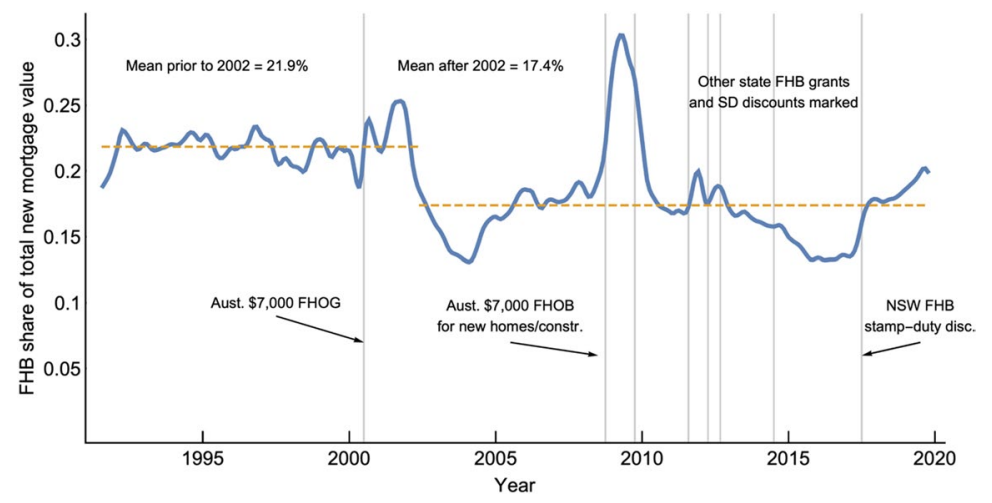

Figure 9. Share of total owner-occupier bank lending going to first-home buyers (ABS, 2019e).

of the 2000-2006 and 2012-2017 periods should be associated with increases in aggregate equity, given the majority of homeowners not involved in property trading benefit from additional equity without additional mortgage debt. ${ }^{4}$ The puzzle be explained by rapid increases in home equity withdrawal by home owners who are not purchasing, as well as heavy reliance on bank credit for those who are buying properties. This conclusion is supported by the data on home equity withdrawals, which shows a large increase in home equity withdrawals during the 2000-2006 boom (RBA, 2005).

A comparison with the US is informative here. Similar to Australia, the US bank data shows a surge in the balance of revolving home equity loans, rising from $\$ 100$ billion in 2000 to $\$ 480$ billion in 2007 (FRED, 2020), helping to explain the fall in the aggregate home equity pattern seen in the early 2000s boom. However, since 2009 the balance of US equity loans has consistently fallen from $\$ 600$ billion to $\$ 310$ billion, while prices have been slowly rising since 2012. More conservative bank lending against home equity during a period of rising prices has seen US aggregate equity rise to $64 \%$ in 2020; its highest point since 1991 (see Figure 8). 
In Australia, perhaps because the house price fall of 2008 was minimal, home equity withdrawal has continued apace and with it the monetization of land rents.

\subsection{Government spending and taxation}

The third pillar of the rentierization of the Australian housing market concerns the wider role of government in supporting a model of housing provision in which land rent extraction is both enabled and maintained. We noted in Section 3.1 that a bias towards landed-property as the preferred from of tenure was a feature of the Australian policy mix and cultural traditions from the early part of the $20^{\text {th }}$ century. A range of both direct and indirect subsidies and taxes have solidified this arrangement, complementing the changes in the financial system.

\subsubsection{Direct assistance}

Direct assistance from the state was provided through the long-term use of subsidies for homebuying, via various forms of deposit assistance and First Home Buyers Grants (FHBGs). Since the 1960s these types of grants been used to support home ownership for low-income households, but since 2000 they have been adopted by states and territories, as well as the Federal government, to support prices in cyclical downturns (Eslake, 2013). In Figure 9 the effect of these grants in attracting new buyers to the market can be seen. The value of these grants is mostly capitalized into home price, offsetting any intended affordability benefits for buyers (Dungey et al., 2011). The main effect of these popular discretionary fiscal policies is thus to support the flow of economic rents to homeowners, even while they are promoted as being of benefit to non-homeowners.

As well as fiscal subsidies, public expenditure has seen a shift away from direct provision of public housing to subsidizing rents and private housing investors through systems such as the National Rental Affordability Scheme (NRAS). Introduced in 2008, this scheme paid housing investors a fixed subsidy of $\$ 11,000$ per year $(\$ 8,000$ when the scheme began) to rent to qualifying tenants at $20 \%$ below the market rent. Unfortunately, not only was the benchmarking to market rents easy to game by inflating market rent estimates, the subsidy was far in excess of the $\$ 4,000$ rent discount required to meet the $20 \%$ discount in the typical suburb these homes were in. It has been estimated that this scheme was, on net, a billion-dollar fiscal transfer to selected housing investors with little benefit to renters (Coates \& Horder-Geraghty, 2019).

\subsubsection{Indirect assistance}

Indirect financial assistance via the taxation system has provided an even more significant form of government support for home ownership and rent extraction in the Australian housing market than direct subsidies. Most notably, Australians have paid no tax on capital gains from their primary residence, nor on any form of imputed rent (i.e the value of occupation homeowners receive from their asset), with the exception of an eight-year period between 1915 and 1923 (Pawson et al., 2020 , p. 140). This contrasts with the UK, for example, where imputed rent taxation was charged up until the 1960s. 
In response to rapid house price inflation in the 1970s, in 1985 the Australian government did introduce a capital gains tax (CGT) that also applied to housing. This was applied using an indexation method, allowing asset owners to index the purchase price by inflation to pay this tax on real realized gains. Owner-occupiers were exempted from this tax, as in nearly all advanced economies. However, in 2001, the CGT rules were changed to remove indexation and instead provide a $50 \%$ discount to the capital gains tax rate on assets owned for more than one year. This meant housing investors who speculated on relatively short-term price movements were provided with a major tax advantage compared to those who relied on long-term ownership and incomes from rents. For example, under the indexation method, a $\$ 100,000$ capital gain realized after two years when inflation was $2 \%$ would have been taxed as a $\$ 96,000$ income, whereas under the discount method it would have been taxed as a $\$ 50,000$ income - a massive tax advantage.

Investors have also been able to deduct the (nominal) operating costs, including interest costs, against income from any source. This process is called 'negative gearing' as it can involve deductions exceeding rental incomes. A recent study found that the combination of negative gearing and the CGT discount allows investors to reduce and defer personal income tax, at an annual cost of $\$ 11.7$ billion to the public purse (Daley \& Wood, 2016).

These arrangements complement Australia's liberalized mortgage market since they encourage investors to borrow to reduce their effective tax rate. One analysis found that the real effective tax rate for an investor borrowing at an $80 \%$ loan-tovalue ratio is $20 \%$, around half that of an investor borrowing nothing (Daley \& Wood, 2016). Thus the Australian tax regime further reinforces the drive towards rent extraction and the housing-finance cycle described in Sections 2.2 and 3.2.

Australian states do have land value taxes, unlike many advanced economies. However, most state land tax systems do not apply to owner-occupiers and also contain numerous exemptions, including minimum land value thresholds, again enabling rent extraction. As a result, while home values have more than doubled as a share of GDP since the late 1990s, land taxes make up just $10 \%$ of state revenue, up from around $8 \%$ in the mid-1990s (ABS, 2019d). Stamp duty is the only significant tax on land rents, but even this has only increased from $10 \%$ of state revenues in the mid-1990s to $20-25 \%$ since the early 2000 s, despite the tripling of house prices.

Taken together, these fiscal policies ensure the economic rents from landed property are largely privatized. They make home ownership more attractive as a financial investment than other financial assets, as well as a more attractive form of tenure. The generous CGT discount and tax-offsetting arrangements have biased the Australian private rented sector towards rent extraction from rising prices rather than long-term flows of income.

\subsection{Summary}

This section has traced how shifts in the housing and land markets in Australia - in particular the mass privatization of social housing in the 1960s and 1970s combined with the liberalization of the financial sector to drive up land and house 
Table 2. Comparison of housing rentierization symptoms.

\begin{tabular}{|c|c|c|c|c|c|}
\hline Country & $\begin{array}{c}\text { Real price } \\
\text { growth } \\
2000-2020(\%)\end{array}$ & $\begin{array}{l}\text { Mortgage debt } \\
\text { to GDP ratio } \\
(\%)\end{array}$ & $\begin{array}{l}\text { Social rental } \\
\text { housing ( } \% \text { of } \\
\text { stock) }\end{array}$ & $\begin{array}{l}\text { Home-ownership } \\
\text { rate change } \\
\text { 1990-2016 (\% } \\
\text { point) }\end{array}$ & $\begin{array}{l}\text { Has housing } \\
\text { loan ( } \% \text { of age } \\
15+\text { survey } \\
\text { respondents) }\end{array}$ \\
\hline Australia & 126 & 95 & 4 & -3 & 38 \\
\hline Canada & 155 & 71 & 3 & 6 & 36 \\
\hline France & 78 & 46 & 14 & 3 & 30 \\
\hline Germany & 23 & 36 & 3 & 8 & 21 \\
\hline Italy & 3 & 22 & 4 & 5 & 17 \\
\hline Japan & -27 & 49 & 3 & 0 & 17 \\
\hline Korea & 41 & 19 & 9 & 7 & 26 \\
\hline Netherlands & 17 & 71 & 38 & 15 & 46 \\
\hline United States & 31 & 5 & 4 & 0 & 34 \\
\hline United Kingdom & 78 & 67 & 17 & -4 & 27 \\
\hline
\end{tabular}

Sources: Social housing figures from OECD (2020), real house price growth is from Mack \& Martínez-García (2017), survey respondents with housing loans is from Demirguc-Kunt et al. (2018), mortgage debt to GDP is from Helgi Library (2020), and change in homeownership rate is from Kohl (2018) using the closest years with available data to the 1990 start and 2016 end dates.

prices in Australia. These increasing land rents were privately captured through a highly supportive tax regime and monetized through home equity withdrawal and rents on investment housing. These dynamics help explain the extraordinary returns to housing and rising land values that Australia has witnessed over the past few decades, evidenced in Figures 1 and 2 in Section 3.

It is true that their have been similar dynamics in other advanced economies. However Australia does stand out in comparative perspective on some key aggregate rentier indicators even compared to Anglo-Saxon liberal market economies such as the US, Canada and UK, as shown in Table 2. Australia is either ranked 1st or 2nd in terms of house price growth since 2000, the mortgage-debt to GDP ratio, the proportion of social rental housing, the change (fall) in homeownership rate since 1990 and the proportion of the working age population with a home loan. In summary, it can be viewed as an exemplary case of housing market rentierization. The next section considers why renterization has become so entrenched in Australia and policy alternatives.

\section{Discussion and policy alternatives}

\subsection{The resilience of the Australian model and the role of interest rates}

Why then, has Australia's rentierized housing market model, complete with rising levels of household debt and rising inequality of access to home ownership, persisted for so long? One reason is that, unlike almost every other advanced economy, Australia did not endure significant house price falls during the financial crisis of 2007-8, nor experience a technical recession. Its financial system emerged relatively unscathed. Active government policy responses, including lowering interest rates, which flowed through the variable rate mortgage market, and stimulus payments for home buying, played an important role. In addition, as described in Section 3.3, it was rental investors - typically on higher incomes and owning existing property - that drove the Australian mortgage credit boom in the run-up to the financial crisis, meaning the country was better able to absorb income shocks and price falls (Bullock, 2019). 
The relative financial stability of the Australian economy may be one reason why, despite increasing public pressure, policy makers have been reluctant to enact significant structural reforms to the Australian housing sector. There has been some acceptance by policy makers that financial deregulation, coupled with a generous property taxation regime, has contributed to the growing demand for housing and the resulting increase in the home price-to-income ratio in Australia (Ellis, 2006). However, rather than question the logic of these policies, most recently there has been a renewed interest on the supply side, despite evidence that new supply has more than kept pace with housing demand (Kendall \& Tulip, 2018; Murray, 2021). In particular, there seems to be a reluctance to challenge ever-expanding rates of mortgage lending as a means of controlling house prices.

One argument that has recently come to the fore is that it is low real interest rates - rather than financial liberalization or supportive tax policies - that are the key demand-side driver of housing and house prices (Saunders \& Tulip, 2019; and see Miles \& Monro, 2019 for the UK case). Low interest rates enable households to take out larger mortgages relative to their incomes as their debt-servicing ratio falls, while reducing the risk-adjusted interest rate at which returns to housing are capitalized for investors.

This approach helps explain the puzzle of why housing rents have not kept pace with house prices, but have tracked incomes (in Australia and other countries). Since rent prices reflect, in a pure sense, the demand for housing as a consumption good, the explanation for the discrepancy must be a rise in demand for housing as a financial asset. Since low real interest rates are a global phenomenon not unique to Australia, caused by factors such as ageining populations and technology, there is assumed to be little financial policy makers can do to ameliorate this natural increase in asset demand. Rather, the focus should switch to increasing supply.

But low interest rates alone do not appear to cause high home prices. Throughout the 1960s mortgage interest rates were similar to those in the 2010s in Australia (see Figure 10), yet prices relative to incomes were lower. If we take total imputed housing rents relative to GDP compared to total land value, we can estimate a land capitalization rate - a proxy for the effect of interest on asset prices - back to 1976 (the orange line in Figure 10). This shows a steady decline, despite rising, then falling, interest rates.

High interest rates will clearly discourage borrowing. However, low interest rates are a necessary, but not sufficient, condition for high asset prices. The sufficient conditions, we would argue, are the liberalization of the mortgage market to remove credit constraints, and a favourable fiscal and tax regime that favours landed-property both as a form of tenure and financial asset. When credit for housing is constrained in some way, and where potential home buyers have alternative ways to access secure housing, the effect of low interest rates on inflating residential property values is curtailed.

The housing policy choices many countries have adopted - with Australia perhaps the canonical example - are not choices that make sense if the aim is keep house prices stable relative to incomes. Indeed, recent empirical research suggests liberalizing mortgage credit has actually led to lower levels of home ownership as affordability has worsened across many advanced economies (Kohl, 2018). So what options 


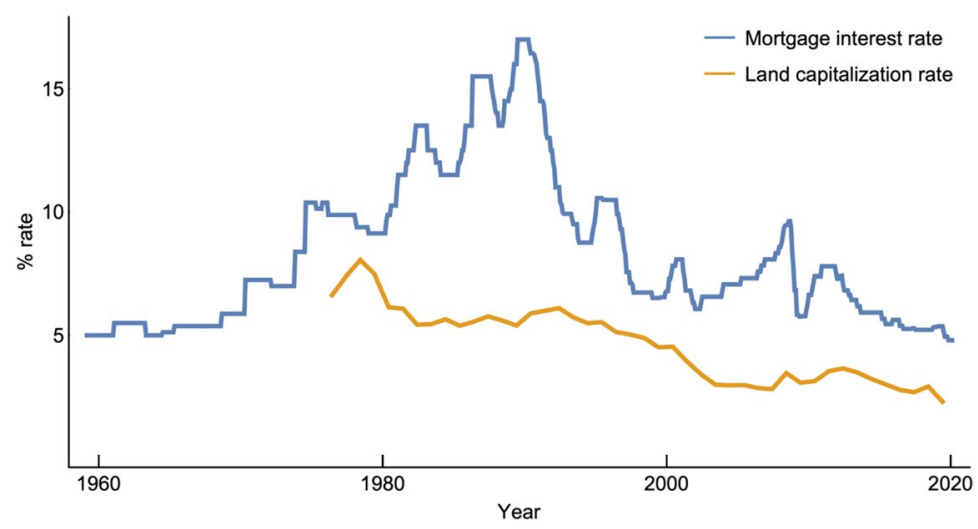

Figure 10. Long-term view of interest rates and land capitalization. Sources: Land capitalization rate is the sum of housing rent and imputed owner occupier rent from ABS (2019b) divided by total residential land value in $A B S$ (2019c). Mortgage interest rate is the standard variable rate for outstanding owner-occupied loans from RBA (2020).

across the three policy areas we have identified in this paper - finance, fiscal and housing policy - are worth considering to reverse the process of rentierization?

\subsection{Financial policy options}

While the central bank could raise interest rates to reduce home prices, historically high household debt levels and the high proportion of Australian households with variable rate mortgages makes such a policy politically and economically unpalatable and may increase financial instability.

Macroprudential policy, which aims to repress the flow of credit via sector-specific regulations such as increasing Loan-to-Value or Loan-to-Income ratios for mortgages, would seem a more effective option to reduce home prices towards more affordable levels (Wijburg, 2021). Such a policy has been used successfully in Switzerland and Singapore (Haila, 2015). The likely effect of macro-prudential policy tools in Australia was demonstrated after the Royal Commission into Misconduct in the Banking, Superannuation and Financial Services Industry in 2017. To avoid the risk of being caught contravening minimum legal lending standards, banks tightened access to housing credit. This came in the form of lower loan-to-value ratio and higher interest rates for investor buyers compared owner-occupiers. The result was an immediate fall in prices and increase in first home buying. It may also be worth considering revisiting the credit controls (described in Section 3.3) used in Australia in the 1950 s and 1960s which favoured investment in to new housing rather than existing and helped increase homeownership.

Financial regulation of private mortgage lending can be complemented by direct public subsidies and financing of social and public housing to develop new non-market-priced housing and support lower income households. Currently the National Housing Finance and Investment Corporation (NHFIC) acts as a 'bond aggregator' to fund social housing projects. However, being backed by government, 
these AAA-rated bonds sell at an unnecessary interest rate premium, adding cost to this funding mechanism compared to direct public financing of social housing which is exposed only to the official cash rate. Though subsidies are still required to create cheap non-market housing alternatives, the NHFIC system subsidizes bond investors rather than housing suppliers or occupants.

\subsection{Fiscal policy options}

Property taxation would seem ripe for reform. Taxes should focus on land rents, such increasing residential property values or developers' and landlords' windfalls from changing land use. Taxing away future rents would strongly push against speculative housing investment. A annual land value tax on primary residences as well as investor housing would be the obvious policy option, introduced at a low initial rate and with options for delayed payment or equity withdrawal for those on low incomes. Tax advantages available to housing investors such as negative gearing and discounted capital gains taxes should also be scrapped to reduce investor competition for home buying (Daley \& Wood, 2016). These tax breaks simply allow investors to set market prices for housing that factor in the value of these tax concessions.

There are clearly political limits when considering these tax reforms, given the influence of corporate lobbyists in Australia (Gurran \& Phibbs, 2016; Jacobs, 2015). The Australian Labor Party promised reforms to negative gearing and capital gains tax discounts at the 2019 federal election only to face major opposition by vested interests and lose the election. This included a well funded TV advertising campaign by the major property developers warning about the crash in property prices that would occur if a Labour Government was elected. Nevertheless, if the rate of home ownership continues to fall in Australia a sizeable constituency may emerge in favour of such reforms.

\subsection{Housing policy options}

On housing policy itself, there are two obvious areas for reform. First is to remove the way that the planning system generates windfall economic rents for landowners. In Germany, local authorities cap land values at pre-permission prices at the time planning permission is granted, giving public authorities the right to acquire land for infrastructure at a reasonable cost. In contrast, in Australia the landlord gains the windfall uplift from planning permission (Murray \& Frijters, 2017). A betterment tax, or value capture mechanism, can capture these economic rents for the public while removing some of the incentive for private landowners to delay development to capture higher value planning changes in the future.

A second reform could involve direct public involvement in new housing supply. This could perhaps take the form of a publicly-owned housing developer with a mandate to compete on price and meet ambitious sales targets, regardless of whether these sale reduce their overall economic return. While Australia still has some legacy public housing developers (such as Landcom in NSW), they are small and not 
incentivised to use their power to supply new housing to affect wider market prices. Not-for-profit housing developers could be supported in their provision of new housing below market prices through access to public prizes or subsidies for achieving timely development.

One solution would be to set up a public housing institution with a sole objective of maintaining housing price stability. Just like central banks determine the price of money - the interest rate - using their ability to supply reserves, a 'central housing bank' could use its ability to supply and sell new housing to set a 'home price corridor' and ensure home prices do not rise rapidly, while dampening potential falls in prices and construction declines during crisis periods (Murray, 2020b). A feature of this type of new institution is that is enacts a widely accepted modern type of price-stabilising intervention in asset markets. At the same time, it can be used to provide non-market dwellings through alternative stable tenures for households, such as 1) renting in the private market to help stabilize rents; 2) using dwellings for public housing at discounted rents; or 3) selling dwellings to social housing providers at discounted prices.

Just as Australia's public housing policies of the 1950s and $60 \mathrm{~s}$ enabled a generation to access secure housing, and ultimately homeownership, this modern variation could do the same by providing alternative ways to access decent housing, reducing pressure on households to leverage into private housing markets and reducing rentier incentives in the process.

Finally, boosting the rights of private renters in Australia would also relieve the pressure to purchase housing by offering secure lower-cost housing alternatives. A recent survey of Australian renters found a majority of renters living in poor quality homes but afraid to request repairs due to being on insecure tenancies and struggling with rental affordability and cost of living pressures (CHOICE, 2019). Renting should not be an inferior alternative to home ownership for residents.

\section{Conclusion}

This article has developed the concept of housing market 'rentierization' to describe the shift in the treatment of housing away from its use as a consumption good to a financial asset from which economic rent can be extracted. This dynamic goes beyond the financialisation of housing that has been the focus of attention in recent literature. Equally, low interest rates are also not sufficient - on their own - to explain rising house prices. Rather, rentierization involves structural and systemic policy changes, and alignment across the land and housing, fiscal and financial policy spheres that are self-reinforcing. They will naturally require structural rather than marginal changes to policy.

Australia is a canonical example of this process and we explored how rentierization occurred since World War II. We traced how a strong political and cultural preference for private landed home ownership combined with the liberalization of the financial sector to drive up land and house prices. These increasing land rents were privately captured through a highly supportive tax regime and monetized through home equity withdrawal and rents on investment housing. Returns to owning 
housing in Australia now dominate economic incomes and the prospect of capturing these rents now dominates investment decisions and public investment and subsidies.

The findings in this paper support the case proposed in other recent contributions that property ownership is becoming a more important determinant of wealth and class than occupation (Adkins et al., 2020; Arundel, 2017; Fuller et al., 2020) and that homeownership itself has become something of a 'false promise' (Arundel \& Ronald, 2021) as larger cohorts, in particular the young, are priced out.

Australia serves as an important case given that the levels of home ownership in the country have not increased since the 1960s, in contrast to other advanced economies, meaning the distribution of land rents has not increased. Australia's system, despite being so clearly 'rentierized', has proven relatively resilient to economic and financial shocks, in part because it enables wealthier, rentier households to take on more risk in an effort to increase their land rents. Nevertheless, the current economic downturn may offer a glimpse of hope. As rates of home ownership fall, renters struggle to make ends meet and central banks run out of policy space, with interest rates already at rock-bottom, reforms that previously appeared politically infeasible - such has higher property taxes, limits on mortgage credit expansion, or some form of public housing program - may gain traction.

In the absence of such reforms, the rentierization of Australia housing, and its symptoms, of rising tenure and intergenerational inequality between home owners and renters, rising household debt and a worsening affordibility in its major urban centres, will likely worsen.

We hope the concept of rentierization will prove a useful conceptual framework for studying the evolution of housing markets in other economies. Further research in to those countries that have resisted some of the policy developments outlined in this paper, for example East Asian countries such as Singapore and South Korea where the state has played a much larger role in land ownership and determining land useage, may be particularly fruitful. By comparing the distribution and allocation of land rents to private and public sectors, informative cross-country comparisons could be drawn to aid policy development.

\section{Notes}

1. Christophers (2019) uses the term rentierization in a similar fashion to describe the shift in the UK economy that has occurred since the 1970s, also arguing that financialisation fails to capture the breadth of policy developments that enabled rentier interests to flourish across different sectors of the economy, including monetary and fiscal policy shifts.

2. Described in detail by Silberberg (1975).

3. Calculated for Australia as (Change in housing stock value - Housing capital investment + Net rents) / Total employee compensation); and for Sydney as (Change in median Sydney dwelling value + Median house rent) / Median NSW full-time wage) (ABS 2019b, 2019g, 2019h; SQM, 2019).

4. For example, if housing turnover is $5 \%$ in a year where prices grow $10 \%$, the $95 \%$ of homeowners at the end of the year who did not purchase get additional equity worth $10 \%$ of their housing stock from the price-setting behaviour of these marginal buyers. Even if the $5 \%$ of new buyers borrowed $100 \%$ of their home value, that is an increase 
in borrowing that is at most $5 \%$ of the value of the housing stock. In this example, the increase in equity is twice as high as the increase in mortgage debt, meaning that the aggregate measure of home equity - value of housing stock minus value of mortgages - should be increasing during this price boom.

\section{Acknowledgements}

Research for this paper was undertaken whilst Ryan-Collins was a Visiting Scholar at the University of Sydney from November-December 2019, funded by the Henry Halloran Trust. The research was also supported by a grant from the Thirty Percy Foundation. The authors would like to thank Peter Phibbs and Giorgos Galanis for comments on an earlier draft and three anonymous referees.

\section{Disclosure statement}

No potential conflict of interest was reported by the authors.

\section{Notes on contributors}

Josh is Head of Finance and Macroeconomics at the UCL Institue for Innovation and Public Purpose. His research interests include the economics of land and housing, money and banking and sustainable finance. He is the author of three books, two co-authored: Where Does Money Come From? (2011, New Economics Foundation); Rethinking the Economics of Land and Housing (2017, Zed books), and Why Can't you Afford a Home (2018, Polity). He has published in journals including Socioeconomic Review, Ecological Economics, Nature Climate Change and Environment and Planning A: Economy and Space. He previously worked for eleven years as an economist at the London-based think tank, the New Economics Foundation.

Cameron is a Post-Doctoral Research Fellow at the Henry Halloran Trust at The University of Sydney. He is a specialist in housing economics, urban development, environmental economics, rent-seeking and corruption. His work has featured in journals including Energy Policy, The Journal of Housing Economics and the Journal of Economic Behaviour and Organisation and he has a co-authored book, Game of Mates: how favours Bleed the Nation based on his $\mathrm{PhD}$ studies at University of Queensland. He previously worked as an economist for the Queensland Government and in the property market.

\section{ORCID}

Josh Ryan-Collins (D) http://orcid.org/0000-0003-4498-6329

\section{References}

Aalbers, M. B. (2016) The Financialization of Housing: A Political Economy Approach (London: Routledge).

Aalbers, M. B. \& Holm, A. (2008) Privatising social housing in Europe: The cases of Amsterdam and Berlin, Urban Trends in Berlin and Amsterdam, 110, pp. 12-23.

ABS (2018) 8752.0 Building Activity (Canberra: Australian Bureau of Statistics).

ABS (2019a) 5204.0 - Australian System of National Account, 2018-19 (Canberra: Australian Bureau of Statistics).

ABS (2019b) 5206.0 - Australian National Accounts (Canberra: Australian Bureau of Statistics). 
ABS (2019c) 5232.0 Australian National Accounts: Finance and Wealth (Canberra: Australian Bureau of Statistics).

ABS (2019d) 5506.0 - Taxation Revenue (Canberra: Australian Bureau of Statistics).

ABS (2019e) 5601.0 Lending Indicators (Canberra: Australian Bureau of Statistics).

ABS ( 2019f) 5609.0 Housing Finance (Canberra: Australian Bureau of Statistics).

ABS (2019g) 6146.0- Residential Property Price Indexes: Eight Capital Cities (Canberra: Australian Bureau of Statistics).

ABS (2019h). 6302.0 Average Weekly Earnings, Australia (Canberra: Australian Bureau of Statistics).

Adkins, L., Cooper, M. \& Konings, M. (2019) Class in the 21st century: Asset inflation and the new logic of inequality, Environment and Planning A: Economy and Space, 5(3), pp. $548-572$

Adkins, L., Cooper, M. \& Konings, M. (2020) The asset economy (London: John Wiley \& Sons).

AIHW. (2018) Housing Assistance in Australia 2018: Australia Institute of Health and Welfare Cat. No. HOU, p. 296.

Andrews, D., Sanchez, A. C. \& Johansson, Å. (2011) Housing markets and structural policies in OECD countries, OECD Economic Department Working Papers, no. 836, 0_1. (OECD Publishing).

Arundel, R. (2017) Equity inequity: Housing Wealth inequality, inter and intra-generational divergences, and the rise of private landlordism, Housing, Theory and Society, 34, pp. $176-200$.

Arundel, R. \& Ronald, R. (2021) The false promise of homeownership: Homeowner societies in an era of declining access and rising inequality, Urban Studies, 58, pp. 1120-1140.

Ball, M. (1983) Housing Policy and Economic Power: The Political Economy of Owner Occupation (London: Methuen).

Ball, M. (1985) The urban rent question, Environment and Planning A: Economy and Space, 17 , pp. 503-525.

Beer, A. (1993) 'A dream won, a crisis born?' Home ownership and the housing market, in: C. Paris (Ed) Housing Australia, pp. 147-172 (London: Palgrave).

Berry, M. (1999) Unravelling the "Australian housing solution": The post-war years, Housing, Theory and Society, 16, pp. 106-123.

Bezemer, D., Ryan-Collins, J., van Lerven, F. \& Zhang, L. 2018. Credit where it's due: A historical, theoretical and empirical review of credit guidance policies in the 20th century, UCL Institute for Innovation and Public Purpose Working Paper Series, no. IIPP WP 2018-11.

Bullock, M. (2019) Property, debt and financial sustainability (Perth: Reserve Bank of Australia).

Burke, T. \& Hulse, K. (2010) The institutional structure of housing and the sub-prime crisis: An Australian case study, Housing Studies, 25, pp. 821-838.

Butlin, N. (1985) Australian National Accounts 1788-1983: Australian National University Source Papers in Economic History No. 6(Canberra: Australian National University).

Cameron, G., Muellbauer, J. \& Murphy, A. (2006) Was there a British house price bubble? Evidence from a regional panel, the Department of Eocnomics Discussion Paper Series, Oxford University.

Capozza, D. R. \& Seguin, P. J. (1996) Expectations, efficiency, and euphoria in the housing market, Regional Science and Urban Economics, 26, pp. 369-386.

Case, K. E. \& Shiller, R. J. (1990) Forecasting prices and excess returns in the housing market, Real Estate Economics, 18, pp. 253-273.

CHOICE (2019). Disrupted: The consumer experience of renting in Australia: National Shelter. Available at https://www.shelterwa.org.au/disrupted-the-consumer-experience-of-rentingin-australia/ (accessed 1 July 2020).

Christophers, B. (2015) The limits to financialization, Dialogues in Human Geography, 5, pp. $183-200$. 
Christophers, B. (2018) The New Enclosure: The Appropriation of Public Land in Neoliberal Britain (London: Verso Trade).

Christophers, B. (2019) The rentierization of the United Kingdom economy, Environment and Planning A: Economy and Space. https://doi.org/10.1177/0308518X19873007.

Clayton, J. (1997) Are housing price cycles driven by irrational expectations? The Journal of Real Estate Finance and Economics, 14, pp. 341-363.

Coates, B. \& Horder-Geraghty, J. (2019) Rudd's rental affordability scheme was a $\$ 1$ billion gift to developers. Abbott was right to axe it, The Conversation. Avaialble at https://theconversation.com/rudds-rental-affordability-scheme-was-a-1-billion-gift-to-develope rs-abbott-was-right-to-axe-it-122854

Davis, M. A. \& Heathcote, J. (2007) The price and quantity of residential land in the United States, Journal of Monetary Economics, 54, pp. 2595-2620.

Daley, J. \& Wood, D. (2016) Hot property: Negative gearing and capital gains tax reform: Grattan Institute. Available at https://grattan.edu.au/report/hot-property/ (accessed 20 January 2021).

Demirguc-Kunt, A., Klapper, L., Singer, D., Ansar, S. \& Hess, J. (2018) The Global Findex Database 2017, Measuring Financial Inclusion and the Fintech Revolution, the World Bank (Washington, DC: World Bank).

Doling, J. \& Ronald, R. (2010) Home ownership and asset-based welfare, Journal of Housing and the Built Environment, 25, pp. 165-173.

Duca, J. V., Muellbauer, J. \& Murphy, A. (2011) House prices and credit constraints: Making sense of the US experience, The Economic Journal, 121, pp. 533-551.

Dungey, M., Wells, G. \& Thompson, S. (2011) First home buyers' support schemes in Australia, Australian Economic Review, 44, pp. 468-479.

Ellis, L. (2006) Housing and Housing Finance: The View from Australia and Beyond (Sydney: Reserve Bank of Australia).

Eslake, S. (2013) Australian housing policy: Fifty years of failure. Available at https://www. aph.gov.au/Parliamentary_Business/Committees/Senate/Economics/Affordable_housing_2013/ Submissions (accessed 8 December 2019).

Fernandez, R. \& Aalbers, M. B. (2016) Financialization and housing: Between globalization and varieties of capitalism, Competition \& Change, 20, pp. 71-88.

Forrest, R. \& Hirayama, Y. (2018) Late home ownership and social re-stratification, Economy and Society, 47, pp. 257-279.

FRED (2020a) Households; Owners' equity in real estate, level: Board of governors of the Federal Reserve System. Available at https://fred.stlouisfed.org/series/OEHRENWBSHNO (accessed 20 January 2021).

FRED (2020b) Households; Owner-occupied real estate including vacant land and mobile homes at market value: Board of Governors of the Federal Reserve System. Available at https://fred.stlouisfed.org/series/BOGZ1FL155035015Q (accessed 20 January 2021).

French, S., Leyshon, A. \& Wainwright, T. (2011) Financializing space, spacing financialization, Progress in Human Geography, 35, pp. 798-819.

Fuller, G. W., Johnston, A. \& Regan, A. (2020) Housing prices and wealth inequality in Western Europe, West European Politics, 43, pp. 297-320.

George, H. (1884) Progress and Poverty: An Inquiry into the Cause of Industrial Depressions, and of Increase of Want with Increase of Wealth, the Remedy (New York: W. Reeves).

Gizycki, M. \& Lowe, P. (2000) The Australian financial system in the 1990s, in: D. Gruen \& S. Shrestha (Eds) The Australian Economy in the 1990s, Proceedings of a Conference, pp. 180-215 (Sydney: Reserve Bank of Australia).

Gotham, K. F. (2009) Creating liquidity out of spatial fixity: The secondary circuit of capital and the subprime mortgage crisis, International Journal of Urban and Regional Research, 33, pp. 355-371.

Grenville, S. (1991) The evolution of financial deregulation, in: The Deregulation of Financial Intermediaries, Proceedings of a Conference, pp. 3-35, Reserve Bank of Australia, Sydney. 
Gurran, N. \& Phibbs, P. (2015) Are governments really interested in fixing the housing problem? Policy capture and busy work in Australia, Housing Studies, 30, pp. 711-729.

Gurran, N. \& Phibbs, P. (2016) How the Property Council is shaping the debate around negative gearing, taxes, The Conversation. Available at http://theconversation.com/how-the-property-counci l-is-shaping-the-debate-around-negative-gearing-taxes-61006 (accessed 1 July 2020).

Haila, A. (1988) Land as a financial asset: The theory of urban rent as a mirror of economic transformation, Antipode, 20, pp. 79-101.

Haila, A. (2015) Urban Land Rent: Singapore as a Property State (West Sussex: John Wiley \& Sons).

Harvey, D. (1978) The urban process under capitalism: A framework for analysis, International Journal of Urban and Regional Research, 2, pp. 101-131.

Harvey, D. (1982) The Limits to Capital (New and Fully Updated Edition) (London: Verso).

Hayward, D. (1986) The Great Australian dream reconsidered: A review of Kemeny, Housing Studies, 1, pp. 210-219.

Helgi Library (2020). Mortgage loans (as \% of GDP): Helgi Library. Available at https://www. helgilibrary.com (accessed 20 January 2021).

Hill, M. R. (1959) Housing finance in Australia, 1945-1956 (Melbourne: Melbourne University Press).

Himmelberg, C., Mayer, C. \& Sinai, T. (2005) Assessing high house prices: Bubbles, fundamentals and misperceptions, Journal of Economic Perspectives, 19, pp. 67-92.

Hudson, M. (2010) The Transition from Industrial Capitalism to a Financialized Bubble Economy, Levy Economics Institute: Working Paper No. 627 (Annandale-on-Hudson: Levy Economics Institute), pp. 1-34.

Jacobs, K. (2015) The 'politics' of Australian housing: The role of lobbyists and their influence in shaping policy, Housing Studies, 30, pp. 694-710.

Jones, E. (2003) Nugget Coombs and his place in the postwar order, Drawing Board: An Australian Review of Public Affairs, 4, pp. 23-44.

Jordà, Ò., Knoll, K., Kuvshinov, D., Schularick, M. \& Taylor, A. M. (2019) The rate of return on everything, 1870-2015, The Quarterly Journal of Economics, 134, pp. 1225-1298.

Kemeny, J. (1978) Home ownership and finance capital, Journal of Australian Political Economy, 3, pp. 89-97.

Kemeny, J. (1983) The great Australian nightmare: A critique of the home-ownership ideology. Melbourne: Georgian House.

Kemeny, J. (2005) The really big trade-off between home ownership and welfare: Castles' Evaluation of the 1980 thesis, and a reformulation 25 years on, Housing, Theory and Society, 22, pp. 59-75.

Kendall, R. \& Tulip, P. (2018) The effect of zoning on housing prices: Reserve Bank of Australia Discussion Paper Series 03 (Sydney: Reserve Bank of Australia).

Kent, C. \& Debelle, G. (1999) Trends in the Australian Banking System: Implications for Financial System Stability and Monetary Policy (Sydney: Reserve Bank of Australia).

Knoll, K., Schularick, M. \& Steger, T. (2017) No price like home: Global house prices, 1870-2012, American Economic Review, 107, pp. 331-353.

Kohl, S. (2018) More mortgages, more homes? The effect of housing financialization on homeownership in historical perspective, Politics \& Society, 46, pp. 177-203.

Mack, A. \& Martínez-García, E. (2017) A Cross-Country Quarterly Database of Real House Prices: A Methodological Note, Globalization and Monetary Policy Institute Working Paper 99 (Dallas: Federal Reserve Bank of Dallas).

Meen, G. \& Whitehead, C. (2020) Understanding Affordability: The Economics of Housing Markets (Bristol: Policy Press).

Meen, G. P. (2009) The removal of mortgage market constraints and the implications for econometric modelling of UK house prices, Oxford Bulletin of Economics and Statistics, 52, pp. 1-23.

Miles, D. \& Monro, V. (2019) UK House Prices and Three Decades of Decline in the Risk-Free Real Interest Rate, Bank of England Staff Working Paper, London, 837. 
Muellbauer, J. (2012) When is a housing market overheated enough to threaten stability? in: Property Markets and Financial Stability, RBA Annual Conference Volume. Reserve Bank of Australia, pp. 73-105 (Sydney: Reserve Bank of Australia).

Muellbauer, J. \& Williams, D. (2011) Credit conditions and the real economy: The elephant in the room: BIS papers 64. Available at http://www.bis.org/publ/bppdf/bispap64p. pdf (accessed 20 January 2021).

Murray, C. (2021) The Australian housing supply myth. Australian Planner, 57(1).

Murray, C. (2020b) A 'central housing bank' proposal for a crisis and beyond, Fresh Economic Thinking. https://www.fresheconomicthinking.com/2020/03/a-centra l-housing-bank-proposal-for.html (accessed 20 January 2021).

Murray, C. \& Frijters, P. (2017) Game of Mates: How Favours Bleed the Nation (Brisbane: Publicious).

Murray, C. K. (2020a) Time is money: How landbanking constrains housing supply, Journal of Housing Economics, 49, pp. 101708.

Murray, C. K. \& Frijters, P. (2016) Clean money, dirty system: Connected landowners capture beneficial land rezoning, Journal of Urban Economics, 93, pp. 99-114.

OECD (2020). Affordable Housing Database (Organization for Economic Development and Cooperation). Available at https://www.oecd.org/housing/data/affordable-housing-database/ (accessed 20 January 2021).

Pawson, H., Milligan, V. \& Yates, J. (2020) Housing Policy in Australia: A Case for System Reform (Singapore: Palgrave MacMillan).

Phang, S.-Y. (1996) Economic development and the distribution of land rents in Singapore: A Georgist implementation, American Journal of Economics and Sociology, 55, pp. 489-501.

Poovey, M. (2015) On 'the limits to financialization', Dialogues in Human Geography, 5, pp. 220-224.

Poterba, J. M. (1984) Tax subsidies to owner-occupied housing: An asset-market approach, The Quarterly Journal of Economics, 99, pp. 729-752.

Putland, G. R. (2018) Trickle-Up Economics: Assessing the Impact of Privatised Land Rent on Econoimc Growth, (North Melbourne: Prosper). Available at https://www.prosper.org.au/ wp-content/uploads/2018/04/TrickleUp22.pdf Last accessed 20 Jan 2021.

RBA (2005). Survey on Housing Equity Withdrawal and Injection (Sydney: Reserve Bank of Australia).

RBA (2019). Bank Lending Classified by Sector - D5 (Sydney: Reserve Bank of Australia Money and Credit Aggregates).

RBA (2020). Indicator Lending Rates - F5 (Sydney: Reserve Bank of Australia).

Rognlie, M. (2014) A note on Piketty and diminishing returns to capital, Unpublished paper, MIT.

Rolnik, R. (2013) Late neoliberalism: The financialization of homeownership and housing rights, International Journal of Urban and Regional Research, 37, pp. 1058-1066.

Rolnik, R. (2019) Urban Warfare. Verso Trade.

Ronald, R., Lennartz, C. \& Kadi, J. (2017) What ever happened to asset-based welfare? Shifting approaches to housing wealth and welfare security, Policy \& Politics, 45, pp. 173-193.

Ryan-Collins, J. (2018) Why Can't You Afford a Home? (London: Polity Press).

Ryan-Collins, J. (2019) Breaking the housing-finance cycle: Macroeconomic policy reforms for more affordable homes, Environment and Planning A: Economy and Space, 53(3), pp. 480-502.

Ryan-Collins, J., Lloyd, T. \& Macfarlane, L. (2017) Rethinking the Economics of Land and Housing (London: Zed Books Ltd).

Saunders, T. \& Tulip, P. (2019) A Model of the Australian Housing Market: 2019-01 (Sydney: Reserve Bank of Australia).

Schwartz, H. \& Seabrooke, L. (2008) Varieties of residential capitalism in the international political economy: Old welfare states and the new politics of housing, Comparative European Politics, 6, pp. 237-261. 
Scott, R. H. (1969) The value of land in Australia (Sydney: Reserve Bank of Australia).

Scott, R. H. (1986) The Value of Land in Australia. Research Monograph No. 47 (Canberra: Centre for Research on Federal Financial Relations, Australian National University).

Shahab, S., Hartmann, T. \& Jonkman, A. (2021) Strategies of municipal land policies: Housing development in Germany, Belgium, and Netherlands, European Planning Studies, 29, pp. $1132-1119$.

Silberberg, R. (1975) Rates of return on Melbourne Land Investment, 1880-92, Economic Record, 51, pp. 203-217.

Sommer, K., Sullivan, P. \& Verbrugge, R. (2013) The equilibrium effect of fundamentals on house prices and rents, Journal of Monetary Economics, 60, pp. 854-870.

SQM (2019) Weekly Rents (Sydney: SQM Research).

Stiglitz, J. (2015) The great divide. Penguin UK.

The Economist (2020). Housing is at the root of many of the rich world's problems, The Economist (Special Report on Housing). Available at https://www.economist.com/ special-report/2020/01/16/housing-is-at-the-root-of-many-of-the-rich-worlds-problems.

Troy, P. (2011) The rise and fall of public housing in Australia.

Watson, M. (2010) House price Keynesianism and the contradictions of the modern investor subject, Housing Studies, 25, pp. 413-426.

Wijburg, G. (2021) The de-financialization of housing: Towards a research agenda, Housing Studies, 36, pp. 1276-1218.

Williams, D. M. 2009. House Prices and Financial Liberalisation in Australia, Oxford University Department of Economics Working Paper Series, No. 432.

Wood, G. A. (1990) Housing finance and subsidy systems in Australia, Urban Studies, 27, pp. $847-876$.

Yates, J. (1983) Access to housing finance and the Campbell report: The implications of implementing the recommendations of Chapter 37, Economic Papers: A Journal of Applied Economics and Policy, 2, pp. 101-122.

Yates, J. (1994) Home ownership and Australia's housing finance system, Urban Policy and Research, 12(1) pp. 27-39.

Yates, J. \& Yanotti, M. (2016) Australia's 25 years with a deregulated housing finance system: Looking back and looking forward, in: J. Lunde and C. Whitehead (Eds) Milestones in European Housing Finance, pp. 37-53 (London: John Wiley and Sons, Inc.). 